\title{
A Study of the Consumer Preference towards Electric-bicycles over 2 Wheelers ( Motor Cycles) amongst Youth with reference to Pune City
} Dr. Vasimraja Sayed ${ }^{1}$, Dr. Porinita Banerjee ${ }^{2}$

${ }^{1}$ Assistant Professor, AKI's Poona Institute of Management Sciences and Entrepreneurship, Camp Pune, Maharashtra, India

${ }^{2}$ Associate Professor, AKI’s Poona Institute of Management Sciences and Entrepreneurship, Camp Pune, Maharashtra, India

\begin{abstract}
Article Info

Volume 8, Issue 5

Page Number : 516-520

\section{Publication Issue}

September-October-2021

\section{Article History}

Accepted : 16 Oct 2021

Published : 30 Oct 2021

In the current market where innovation is the key and the customer is ready to pay the price for new products, the introduction of e bicycles in the Indian market is a new trend. The marketers are milking the opportunity of presenting the E Bicycles to the customers as a substitute to other two wheelers which are available in the market. This study aims at finding out the behavior of the consumer and its perception towards E Bicycle. To undertake this study survey method has been used for data collection through convenience sampling of 78 respondents. The data was later processed and interpreted. The findings show that the Consumer is viewing E Bicycles as a better option than the two wheelers in future in the scenario of the rising fuel prices and the environmental issues.
\end{abstract}

Keywords : Consumer Behavior, Perception, Innovation, Market Share.

\section{INTRODUCTION}

The Indian vehicle market is going through a transition state with the increase in fuel prices on one hand and the introduction of electric vehicles on the other. Electric 2 wheelers and 4 wheelers is being promoted by the government as a better substitute to the existing petrol and diesel vehicles. In the midst of all this marketers have introduced a new product in the market in the form of E- Bicycles. An electric bicycle or an e-bike consists of an electric motor which helps in propulsion of the vehicle while riding. In the global market different types of such e bicycles are present in the market and are divided in two major categories: e bicycles which helps the riders to pedal (i.e. pedelecs) and bicycles which has an integrated moped- style working by adding a throttle to the vehicle. Both these categories are different from electric motor cycles as they have the ability to be pedaled by the rider. E bicycles can travel up to 25 to $30 \mathrm{~km}$ per hour with the use of rechargeable batteries. E bicycles which are high powered can run at the speed of $45 \mathrm{~km}$ per hour also. In many countries these e bicycles are increasing their market share as they have become quite popular and are replacing small motorcycles and mopeds. As per the 
Indian law these electric bicycles should have the approval of ARAI (Automotive Research Association of India) Certification is not needed for the bicycles which fall under $250 \mathrm{~W}$ category and having less than $25 \mathrm{~km}$ per hour speed. It does not go through the full testing and should have an exemption from the ARAI.Other vehicles with more power go through testing as per the CMVR(Central Motor Vehicles Rules). Taking the new product through this whole process involves investment of money and time but it gives the assurance of a reliable design of the $\mathrm{E}$ Bicycle. The regional transport offices do not announce these regulations and riders of these $\mathrm{E}$ Bicycles do not need to carry a license, insurance and helmet. Electric Bicycles in India which do not require registration and license are made according to the guidelines by the ARAI.

\section{E- Bicycle manufacturing companies in India: Hero} LECTRO EHX20, GEEKAY Bikes- ECOBIKE PRO PLUS,E-TRIO ASHVA, NIBE Motors, SWAGTRON are the top $5 \mathrm{E}$ Bicycles manufacturing companies in India.

\section{- Hero LECTRO EHX20}

Hero Lectro Electric Bicycle series is one of the innovative products which Hero could ever come up with. The hero has an aspiration of taking over $10 \%$ of the global E-cycle market by 2022. Hero lector cycles are manufactured in the Hero automotive plant located at Delhi NCR, and the design process is carried out in Berlin. Hero Lectro bicycles are designed with a state-of-the-art Electric Drive Unit (EDU) and a Li-ion battery that is adequately concealed in the down tube. It has a Throttle mode (twist and Go mode, which provides a unique experience of cycling without pedaling), a Cruise mode (A-mode with cycling at a fixed speed of $6 \mathrm{~m} / \mathrm{hr}$ powered by the battery), Pedalec Mode (A mixture between battery assist and pedaling which reduces effort by $80 \%$ and the traditional way which is the Pedal Mode.Some of the latest and best Hero Lectro Electric bicycles are HERO LECTRO EHX20, HERO LECTRO F6i, HERO LECTRO C3, HERO LECTRO C4 etc. The HERO ELECTRO E-Cycle price range starts from Rs.23,000 to Rs.1,35,000 approximately. Speaking of the model, HERO ELECTRO EHX20 has a range of $80 \mathrm{~km}$ per charge and has a triple sensor system. The triple sensor system consists of a torque sensor, speed sensor, and crank sensor. The Li-ion batteries are mounted close to the pedals. HERO ELECTRO EHX20 is undoubtedly one of the expensive and luxurious E-cycle. The MRP of HERO ELECTRO EHX20 is Rs.135,000. ${ }^{\mathrm{i}}$

\section{- GEEKAY Bikes- ECOBIKE PRO PLUS}

Geekay Bikes is in the market since 1961, and they have been manufacturing conventional Bicycles \& parts, Electric Bicycles, Electric Pedal Rikshaws\&parts, and batteries. They provide a commitment to offering the best cycles in the market.The latest Geekay electric bicycles raving the market now are ECO BIKE ELITE, ECO BIKE UNI, ECOBIKE PRO, and ECO BIKE PRO PLUS. The Price range varies from Rs.35000 to Rs.48000.ECO BIKE PRO PLUS is undoubtedly one of the innovative products by Geekay Bikes. This is one of the fat-tyre bicycles and has 21 gears which assures comfort and safety. Carrying a powerful motor and a high-capacity detachable battery, it has a USB charging option. ECO BIKE PRO PLUS has a market price of Rs. 43,849 .ii

\section{- E-TRIO ASHVA \&iSWITCH}

E-TRIO is one of the first Indian EV Conversion companies and also the first company with certified E-LCV'S on the road. E-TRIO'S vision is to provide everyone with the most comprehensive range of EV'S 
and to provide affordable mobility. It has a driving three-way change concept which is Decarbonizing Environment, Impacting Businesses, and Transforming Lives. ASHVA has a range of $80 \mathrm{~km}$ per charge, Top Speed of $25 \mathrm{kmph}$, Frame Size of 17" and 26" Tyre. It has a Li-ion battery of 18 ah which provides an extra-long battery range. ASHVA is sold for Rs. 37, 799.iSWITCH provides maximum comfort and durability and a range of $35 \mathrm{~km}$ per charge. It has a top speed of 25kmph, Frame Size of 17" and 26" Tyre. It has a Li-ion battery of 7.8 ah which provides an extra-long battery range. iSWITCH is sold at a price of Rs.32,599.

\section{- $\quad$ NIBE Motors}

NIBE MOTORS specializes in advanced two-wheelers and three-wheelers electric vehicle manufacturing with an environment-friendly goal as of prime importance. It gives priority to research and development and provides cutting-edge technology in the fields of E-Bicycle, E-Scooter, E-Autorickshaw, Li-Ion Batteries, and Regeneration concepts. Its Research \& Developments manufacturing unit is at Nasik.

Interestingly their E-Cycle models are categorized as Gents E-Cycle, Ladies E-Cycle, Postman ECycle, Police E-Cycle, Indian Army E-Cycle, and Lipo E-Cycle. Advantages of NIBE MOTORS ECycles are No License and registration required, zero maintenance drive, Super long battery life, stunning metal body design, advanced Li-Ion battery used, charging time 2-3 hours, smart charger, and has a one-year warranty.NIBE MOTORS E-Cycles has a range of are $50-70 \mathrm{~km}$ per charge, $100-120 \mathrm{~kg}$ loading capacity, and super eco-friendly. ${ }_{\text {iii }}$

\section{- SWAGTRON}

Everything about SWAGTRON is related to mobility. They make hoverboards, skateboards, scooters, and E- bikes. It has a vertically integrated business model which caters to the whole package, which is: Design, Product development, manufacturing, sales, logistics, marketing. The SWAGTRON models available in the market are swagcycle EB-5, Swagcycle PRO, Swagtron EB-7, and Swagtron EB-12. The SWAGTRON E-Cycle price range starts from Rs.39,490 to Rs.79,990.Speaking of Swagtron EB-12, it is one of the coolest, "real feel" city E-bikes. It has $700 \mathrm{C}^{*} 25 \mathrm{~mm}$ cycling tires and has a removable battery. Its maximum load capacity is $120 \mathrm{~kg}$. Charging time is 4-5 hours and has a Shimano 7-speed SIS gear. It also provides a door-to-door warranty of 1 year. The M.R.P of the product is Rs. 79,990 . $^{\text {iv }}$

\section{RESEARCH PROBLEM:}

As the trend is changing more and more companies are investing in manufacturing $\mathrm{E}$ Bicycles in India and are seeing the product as a substitute to motor cycles (two wheelers). The study is oriented towards finding out the Consumer behavior and perception towards the E bicycles and to understand whether the consumer is also perceiving the product as it is perceived by the marketers and will the product be successful in the long run and the marketers should not face the brunt of Marketing myopia.

\section{RESEARCH METHODOLOGY}

Objectives of the Study: The objective of the study is to know the preference of the Youth towards EBiycles as a substitute to 2 wheelers (Motor Cycles) with reference to Pune City.

Research Design:The study is Descriptive in Nature.

Sources of Data: The researcher has collected information for the present study through interviews from the youth who are using motor cycles to commute from one place to another across the city. The secondary data has been collected from Internet, Books and magazines etc. 
Methods of Data collection: A structured Limitations of the Study:

Questionnaire was made keeping in mind the - This study is specifically done in the Pune Urban objectives of the study.

Sample Size: The researcher has interviewed almost 166 respondents out of which 100 respondents have filled the questionnaire diligently, the final sample size of the study after discarding questionnaire with incomplete responses remains 100 .

Sample Area \& Period of study: The research was carried out specifically in Pune Urban Region and the period of the study was from July to Mid October 2021.

Sampling Technique: The researcher has adopted convenient sampling technique for the study. region and the results may differ if conducted in different parts of the state or nation.

- Younger generation who are using motor cycles to commute are taken as a sample for this study and the responses may vary if it will be conducted on the other categories of generation.

- The study is conducted for E- bicycles only and cannot imply in case of a normal bicycle or Emotor Vehicle.

- Findings of the research are based on assumptions that all the respondents have given genuine responses.

\section{DATA ANLYSIS AND INTERPRETATION}

Table.1 Table showing responses of the preferences of the Consumer towards Electric Bicycle over 2 wheeler as a rider choice.

\begin{tabular}{|c|c|c|c|c|c|c|}
\hline OPTIONS & SA & A & $\mathbf{N}$ & $\mathrm{D}$ & SD & TOTAL \\
\hline $\begin{array}{l}\text { I choose electric bicycle over } 2 \text { wheeler as it is more fuel efficient } \\
\text { and work as a money saver. }\end{array}$ & 77 & 13 & 8 & 2 & 0 & 100 \\
\hline PERCENTAGE & $77 \%$ & $13 \%$ & $8 \%$ & $2 \%$ & $0 \%$ & $100 \%$ \\
\hline I choose electric bicycle over 2 wheeler due to its eco friendliness & 32 & 10 & 5 & 35 & 18 & 100 \\
\hline PERCENTAGE & $32 \%$ & $10 \%$ & $5 \%$ & $35 \%$ & $18 \%$ & $100 \%$ \\
\hline $\begin{array}{l}\text { I choose electric bicycle over } 2 \text { wheeler as it resolves my Parking } \\
\text { issue }\end{array}$ & 59 & 21 & 17 & 2 & 1 & 100 \\
\hline PERCENTAGE & $59 \%$ & $21 \%$ & $17 \%$ & $2 \%$ & $1 \%$ & $100 \%$ \\
\hline $\begin{array}{l}\text { I choose electric bicycle over } 2 \text { wheeler to improve my Physical } \\
\text { fitness }\end{array}$ & 60 & 30 & 9 & 1 & 0 & 100 \\
\hline PERCENTAGE & $60 \%$ & $30 \%$ & $9 \%$ & $1 \%$ & $0 \%$ & $100 \%$ \\
\hline $\begin{array}{l}\text { I choose electric bicycle over } 2 \text { wheeler as it is fashionable and } \\
\text { trending. }\end{array}$ & 58 & 27 & 15 & 0 & 0 & 100 \\
\hline PERCENTAGE & $58 \%$ & $27 \%$ & $15 \%$ & $0 \%$ & $0 \%$ & $100 \%$ \\
\hline $\begin{array}{l}\text { I choose electric bicycle over } 2 \text { wheeler for being low on } \\
\text { maintenance }\end{array}$ & 24 & 25 & 20 & 20 & 11 & 100 \\
\hline PERCENTAGE & $24 \%$ & $25 \%$ & $20 \%$ & $20 \%$ & $11 \%$ & $100 \%$ \\
\hline $\begin{array}{l}\text { I choose electric bicycle over } 2 \text { wheeler due to its easy maneuvering } \\
\text { in traffic. }\end{array}$ & 57 & 23 & 10 & 7 & 3 & 100 \\
\hline PERCENTAGE & $57 \%$ & $23 \%$ & $10 \%$ & $7 \%$ & $3 \%$ & $100 \%$ \\
\hline $\begin{array}{l}\text { I choose electric bicycle over } 2 \text { wheeler to its comfort ride in city } \\
\text { condition. }\end{array}$ & 58 & 31 & 9 & 2 & 0 & 100 \\
\hline PERCENTAGE & $58 \%$ & $31 \%$ & $9 \%$ & $2 \%$ & $0 \%$ & $100 \%$ \\
\hline $\begin{array}{l}\text { I choose electric bicycle over } 2 \text { wheeler as it saves my time from } \\
\text { standing in long queues during refeuling. }\end{array}$ & 67 & 23 & 5 & 3 & 2 & 100 \\
\hline PERCENTAGE & $67 \%$ & $23 \%$ & $5 \%$ & $3 \%$ & $2 \%$ & $100 \%$ \\
\hline $\begin{array}{l}\text { I choose electric bicycle over } 2 \text { wheeler due to its low acceleration, } \\
\text { high stability \& safe ride }\end{array}$ & 54 & 14 & 12 & 6 & 4 & 100 \\
\hline
\end{tabular}


Response Category: $\mathrm{SA}=$ Strongly Agree, $\mathrm{A}=$ Agree, N/U=Neutral/Undecided, $\mathrm{D}=$ Disagree, $\mathrm{SD}=$ Strongly Disagree

\section{INTERPRETATIONS}

The above analysis indicates that the youth of Pune City are well aware of the benefits associated with the Electric-Bicycle over the usage of 2 wheelers, they prefer to choose E-bicycle over 2 wheelers for innumerable reasons. Majority of the youth wishes to buy E-bicycle as it serve as a money saver due to its fuel efficiency, eco- friendliness, low on maintenance , easy maneuvering in traffic, low acceleration and also for is safe and comfort ride in city conditions. These innovative $\mathrm{E}$-bicycles are also gratifying the fashion quotient amongst the youth.

\section{CONCLUSION}

The study revealed that the majority of the youth had a positive perception towards the usage of E-bicycle over 2 wheeler. The study further indicates that paramount importance is given towards the fuel efficiency as a serves as a money saver. Frequent surge in the Petrol, CNG and Diesel prices have made the life of the youth's really challenging and they believe the introduction of e-bicycle is an absolute sigh of relief to them. Apart of fuel efficiency there are diversity benefits which are mentioned above. Therefore, it can be concluded that, this product has got great potential in the market and if appropriate awareness would be created the E-bicycle may evolve as a future market leader.

\section{Cite this article as :}

Dr. Vasimraja Sayed, Dr. Porinita Banerjee, "A Study of the Consumer Preference towards Electric-bicycles over 2 Wheelers ( Motor Cycles ) amongst Youth with reference to Pune City", International Journal of Scientific Research in Science and Technology (IJSRST), Online ISSN : 2395-602X, Print ISSN : 23956011, Volume 8 Issue 5, pp. 516-520, SeptemberOctober 2021. Available at doi $\quad$ : https://doi.org/10.32628/IJSRST218578 Journal URL : https://ijsrst.com/IJSRST218578

${ }^{\mathrm{i}}$ https://evduniya.com/ev-india/top-5-electricbicycle-manufacturers-in-india.html

${ }^{i i}$ https://en.wikipedia.org/wiki/Electric bicycle

iii https://www.velospeed.co.uk/advantages-anddisadvantages-of-electric-bikes/

${ }^{i v}$ https://www.slideshare.net/niteshshende/marketsurvey-of-e-bikes-in-pune-city 